\title{
The complementary effect of internal learning capacity and absorptive capacity on performance: the mediating role of innovation capacity
}

\section{Beatriz Forés* and César Camisón}

Departamento de Administración de Empresas y Marketing, Universitat Jaume I de Castelló, Campus Riu Sec, s/n, Castelló, E-12071, Spain E-mail: bfores@emp.uji.es E-mail: camison@emp.uji.es *Corresponding author

\begin{abstract}
Organisations are finding it increasingly more difficult to keep abreast with the pace of change. The continuous rise in the number of business opportunities and the increase in global competition require firms to combine internal and external learning processes to renew and reconfigure existing capabilities and knowledge to enable them to meet environmental demands and to innovate. This study aims to unravel the complex linkage between internal learning capacity and absorptive capacity and at exploring the joint effect of both knowledge generation processes on innovation capacity. This study also proposes innovation capacity as an antecedent of business performance. Using data from 952 industrial Spanish firms and the technique of structural equation modelling, we provide evidence on the joint effect of internal learning capacity and absorptive capacity on innovation capacity. We also show that innovation capacity acts as a catalyst for the effect of learning capacities on business performance.
\end{abstract}

Keywords: dynamic capacities; knowledge management; business performance; structural equation modelling.

Reference to this paper should be made as follows: Forés, B. and Camisón, C. $(\mathrm{xxxx})$ 'The complementary effect of internal learning capacity and absorptive capacity on performance: the mediating role of innovation capacity', Int. J. Technology Management, Vol. X, No. Y, pp.000-000.

Biographical notes: Beatriz Forés Julián obtained her Business Administration and Management Degree from Universitat Jaume I, Castellón in 2004. She obtained her Diploma of Advanced Studies in 2006 (first stage of Doctoral studies). She is currently a Research Fellow of the Generalitat Valenciana.

César Camisón Zornoza is a Business Organisation Professor at the Department of Business Administration and Marketing at the Universitat Jaume I, Castellón. He obtained his Doctoral degree in Economic and Managerial Sciences (Cum Laude and extraordinary prize). He is the Director of GRECO Research Group on Strategy, Competitiveness and Knowledge Management (http://www.greco.uji.es) and the Coordinator of the thematic investigation network RIGCE (Investigation Network in Quality Management and Excellence), in which lecturers from almost all Spanish universities take part. 


\section{Introduction}

In a rapidly changing and dynamic business environment, firm's sustained competitive advantage root in its ability to innovate continuously. Innovation is the mechanism by which organisations produce new products, processes and systems required for adapting to changes in the markets, technologies and forms of competition (Lawson and Samson, 2001).

Recent studies have shown that successful innovation is increasingly dependent on the development and integration of knowledge into the innovation process (e.g., Cassiman and Veugelers, 2006; Kessler et al., 2000; Caloghirou et al., 2004). In order to successfully innovate in a competitive environment, firms should combine different learning activities. In addition to developing a continuous internal learning system (internal learning capacity), firms should be engaged in the acquisition and assimilation of knowledge and technology from the market (absorptive capacity). We thus propose that internal learning capacity and absorptive capacity represent two mutually dependent learning capabilities that have a joint influence on innovation capacity.

Innovation capacity is an outcome of organisational learning (Cohen and Levinthal, 1990). However, as organisational innovation and learning research suggest, unless organisations convert new knowledge to new products and processes, competitive advantage and superior performance will not be obtained (Bierly et al., 2009; Grant, 1996; Hitt et al., 1996; Kogut and Zander, 1992). In this vein, we suggest that innovation capacity acts as a catalyst for the joint effect of organisational learning capacities on business performance.

In addition, despite rapid growth of organisational learning literature, there is still no systematic measurable approach available for distinguishing the components of the construct from each other and from innovation capacity. For instance, the majority of empirical studies have measured absorptive capacity by R\&D expenditure or number of patents, which are also commonly used to measure innovation, treating it as a 'static resource' rather than a process or a capability [Lane et al., (2006), p.838]. We provide a clear delimitation of internal learning capacity, absorptive capacity and innovation capacity and develop reliable and valid scales to measure them. Therefore, the general goal of this study is to determine conceptual and empirical boundaries of the three related organisational capabilities and advance their understanding by empirically examining their relationships.

Specifically, this paper is organised as follows. Firstly, we briefly review the literature on organisational learning (internal learning capacity and absorptive capacity) and innovation capacity. Having determined this theoretical framework, we then construct our conceptual model and the research hypothesis. Then, we present the empirical research design and the methodological aspects. We empirically validate the hypothesis derived from the theoretical model by means of an electronic survey completed by 952 Spanish industrial firms, using structural equations modelling. This is followed by a statistical analysis of the results. Finally, the most relevant limitations and contributions of the study are presented. 


\section{Theoretical framework}

\subsection{Organisational learning}

Organisational learning is a process through which an organisation increases its knowledge base to advance its capabilities, change and improve its effectiveness. Learning can occur from sources within the organisation, as well as from the external sources. In industries in which knowledge and know-how is critical, a firm relies on both sources; that is, it enhances its knowledge base by experimenting and creating new knowledge internally and by obtaining as well as assimilating existing knowledge from outside (Kessler et al., 2000). Therefore, successful innovation capacity increasingly depends on the development and integration of both types of knowledge generation activities (Cassiman and Veugelers, 2006).

In light of the above issues and according to studies such us those by Goh and Richards (1997) and Jerez-Gómez et al. (2005), we distinguish between two interrelated components of the organisational learning construct: internal learning capacity and absorptive capacity. The justification of the integration of both learning capabilities on the same construct is based on extensive theoretical and empirical evidence in the strategic literature. On the one hand, following the study of De Clercq and Dimov (2008), we suggest a variety of mechanisms that explain why internal learning capacity in a particular domain develops domain-specific absorptive capacity.

Firstly, the diversity and depth of the knowledge base provide the firm with different frames of reference, standards, languages and codes which give the firm a more comprehensive understanding of the new information it receives, increasing its ability to scan and identify valuable tacit knowledge in the environment. Internal learning capacity generates the ability to access and select external opportunities better and faster (Cohen and Levinthal, 1990).

Secondly, a larger prior knowledge base facilitates more abstract mapping of the domain of the firm's activity and allows for a higher level of articulation and codification of its knowledge base. This abstract representation leads to improved assimilation and integration of the information into the existing knowledge base.

Thirdly, and according to Cohen and Levinthal (1990) the diversity of the knowledge base will augment the organisation's capacity for making new linkages and associations between new external knowledge and pre-existing concepts. Knowledge developed internally, therefore, enhances the firm's ability to incorporate additional knowledge into its internal processes (Arora and Gambardella, 1994) and apply it for commercial ends through its incorporation into the firm's operations (Van den Bosch et al., 1999). Bearing in mind the previous studies, we can thus state that internal learning capacity is required to acquire, assimilate and transform knowledge from outside the boundaries of a firm and apply it to innovation (Bierly and Chrakrabarti, 1996; Cohen and Levinthal, 1990).

On the other hand, studies such us the one by Haro-Domínguez et al. (2007) demonstrate that absorptive capacity that the degree of absorptive capacity developed by Spanish service firms positively affects the internal development of technology positively. Soo et al. (2007) also show a positive influence of absorptive capacity on internal learning capacity. In this vein, their study posits that absorptive capacity has a positive influence on creativity and problem solving, both crucial components of firm's internal learning capacity. Specifically, these researchers show that the greater the capacity of an organisation or single individual to absorb external knowledge, the more 
likely it is to act upon that knowledge (to use and combine this knowledge in new ways) and to learn from that knowledge. Based on these previous studies, we suggest that internal learning capacity and absorptive capacity are interrelated manifestations of organisational learning construct.

\subsubsection{Internal learning capacity}

This study defines the internal learning capacity concept as the capability of an organisation to sustain a continuous internal learning system (Bontis et al., 2002) for the creating, processing, disseminating and embodiment of new knowledge that has a potential influence in the organisational behaviour and its status quo in the organisational routines, systems and structures.

In this context, the internal learning capacity occur when members of the organisation create and transfer new ideas and knowledge inside the firm boundaries. Individuals come up with new ideas concerning the improvement of products and processes. All organisational learning occurs through individuals but it is more than the cumulative result of organisational employee's learning. Therefore, the internal learning capacity does not occur until the knowledge is shared and transferred throughout the organisation and integrated with other knowledge areas (Un and Cuervo-Cazurra, 2004). Considering the implicit idiosyncrasy and complexity of the internal learning capacity, we can affirm that it constitutes a difficult capacity to imitate, replicate and transfer leading to innovativeness (Day, 1994).

As pointed out by Kessler et al. (2000), knowledge creation and integration depend mainly on organisational culture factors such as participative decision-making and managerial commitment. Specifically, this study focuses on systems perspective and managerial commitment dimensions proposed by Jerez-Gómez et al. (2005) to describe internal learning capacity since the dimensions related to openness and knowledge integrations are integral part of absorptive capacity construct.

Systems perspective entails bringing the organisation's members together around a common identity (Jerez-Gómez et al., 2005). The organisation promotes employees' commitment to the strategic goals and employees ensure that their tasks and work contributes to attaining them (Goh and Richards, 1997). Considering the dynamism of the current environment, individuals need to help each other to develop their tasks and work in a coordinated manner. Therefore, structures and systems in the organisation need to encourage employees to communicate across functional boundaries. Specifically, teamwork allows to share knowledge, perceptions and beliefs among organisational members more easily and efficiently and to reduce misunderstandings among employees (Nonaka, 1994).

Managerial commitment reflects the important role of managers, especially top managers, in fostering organisational learning by building a common understanding about the learning process and coordinating and transferring knowledge across organisational units (Nonaka, 1994; Schein, 1993). For developing a learning organisation, managers would need to articulate a strategic view of learning, create a climate of egalitarianism, trust and empowerment (Boynton et al., 1994; Jerez-Gómez et al., 2005). Organisational reward and recognition systems are crucial components to reinforce employee's commitment to learning and change. 


\subsubsection{Absorptive capacity}

In 1989 Cohen and Levinthal defined the absorptive capacity of a firm as its ability to recognise the value of new external information, assimilate it and apply it to commercial ends. They sustain the idea that a firm's ability to acquire knowledge from its external environment is a by-product of its own R\&D. As a result of this work, R\&D began to be considered as a key player in organisational learning and innovation.

In 1990, the authors revised their original definition based on industrial organisation economics and developed a more comprehensive explanation of the construct with greater emphasis on the processes underlying this type of organisational learning.

Since the appearance of these definitions, which can be situated within the framework of technological knowledge, surprisingly few review articles have revised the definition of the concept of absorptive capacity [see Lane and Lubatkin (1998), Van den Bosch et al. (1999), Zahra and George (2002) and Lane et al. (2006) for an exception].

Zahra and George (2002) reconceptualise the construct as a set of organisational routines and strategic processes by which firms acquire, assimilate, transform and apply external knowledge in order to produce a dynamic organisational capacity. The traditional three-dimensional model introduced by Cohen and Levinthal (1989) is thus reformulated to include a fourth dimension: transformation capacity. These authors further suggest that these dimensions can be integrated within two complementary components:

a potential absorptive capacity (PACAP), which comprises knowledge acquisition and assimilation capabilities

b realised absorptive capacity (RACAP), which includes knowledge transformation and application capabilities.

Acquisition is defined as the ability to recognise, value and acquire the external knowledge that is critical to a firm's operations (Lane and Lubatkin, 1998; Zahra and George, 2002).

Assimilation refers to the firm's capacity to absorb external knowledge. It can also be defined as the routines and processes that allow the firm to understand, analyse, interpret and include information from external sources (Szulanski, 1996; Zahra and George, 2002).

Transformation refers to the firm's ability to develop and refine routines that facilitate the transfer and combination of existing knowledge with newly acquired and assimilated knowledge. The main objective of this ability is to find out how to reconfigure or adapt the new knowledge to the reality and specific needs of the organisation (Zahra and George, 2002).

Application refers to the firm's ability to apply new external knowledge commercially in order to achieve organisational objectives (Lane and Lubatkin, 1998). It can also refer to the routines that allow firms to refine, extend and leverage existing competences or to create new ones by incorporating acquired and transformed knowledge into its operations (Zahra and George, 2002).

Application capacity is often confused in the literature with innovation capacity (Van den Bosch et al., 2003). This conceptual confusion is mistaken, since the two constructs refer to different contents. Although absorptive capacity can affect performance and competitive advantage through the exploitation of external knowledge, 
these effects require additional resources and capacities (Zahra and George, 2002), such as innovation capacity (Liao et al., 2007). Moreover, innovation capacity can be influenced both by absorptive capacity and internal learning capacity.

\subsection{Innovation capacity}

We consider innovation capacity as the manifestation of internal learning capacity and the absorptive capacity, that is a final result (Zahra and George, 2002; Winter, 2003). From this perspective, firm's innovation capacity is a complex ability in which new knowledge and ideas are continuously applied to commercial ends, that is, to change the offerings (product innovation) and the ways it creates and delivers those offerings (process innovation) (Smith et al., 2005; Rush et al., 2007) in order to increase or sustain its effectiveness and competitiveness. Knowledge is the output of the learning processes and the input of the innovation capacity.

Specifically, following Liao et al. (2007) and Damanpour and Gopalarkrishnan (2001), we define two dimensions of innovation capacity including process innovation and product innovation.

- Process innovation focuses on the efficiency of internal workings and processes of the company to make, assemble or deliver the product. By doing so, a new process may reduce costs or generate more production for the firm.

- Product innovation is that a firm can provide better, differentiated, improved or new products in the market to meet customer needs. Product innovation focuses on the market. Innovation in products is supported by strong capabilities in quality, efficiency, speed and flexibility (Lawson and Samson, 2001). Process and product innovation, that belong to the area of technical innovation (Liao et al., 2007), are very closely linked and constitute a highly complex process which generally involves all company functions.

\section{Theory and hypotheses}

\subsection{Internal learning capacity, absorptive capacity and innovation capacity}

New ideas and proposals represent the starting point of innovation capacity. Therefore, the internal learning capacity, which reflects the creation of shared mental models and the disposition of organisational members towards learning and change, fosters innovation (Henderson and Clark, 1990).

Specifically, teamwork, internal communication and cooperation, aspects of systems perspective, facilitate innovation capacity as they allow the cross-fertilisation of ideas and integration of knowledge residing in different parts of the organisation, resulting in the development of new products and processes (Kahn, 2001).

Managerial commitment to organisational learning and change also positively influences innovation capacity (Kessler et al., 2000; Prajogo and Ahmed, 2006; García-Morales et al., 2007). Both the strategic leadership and innovation literatures emphasise that managers, especially top managers, greatly influence building capacity for innovation (Damanpour and Schneider, 2006). Managers influence innovation capacity because they establish organisational culture, formulate strategy and control key 
resources. Hence, their commitment to organisational learning and change and their favourable attitude toward innovation build feelings of confidence and provide support to organisational members for proposing new ideas that depart from existing practices, and allocate resources to acquire and implement them (Damanpour and Schneider, 2006).

The empirical research also supports a positive association between internal learning capacity and innovation. For example, Bierly and Chackrabarti (1996) found that internal learning capacity was significantly related to the development of new molecular formulae (NCE) and new drugs (NDA) in the pharmaceutical industry. Kessler et al. (2000) showed that internal sourcing was associated with faster project completion times (innovation speed) and competitive advantage generation. Smith et al. (2005) observed that existing and accessible knowledge in an organisation affects the rate of creation of new products through the firm's knowledge creating capacity.

In spite of the importance of internal learning capacity on innovation, recent studies increasingly stand out that an inward-looking approach to innovation in which the firm relies on its in-house resources and capabilities appears to be a conservative option in a dynamic environment like the current one (Caloghirou et al., 2004). An organisation committed to absorbing external knowledge increases its organisational innovation since it is less likely to miss the opportunities created by emerging market demands as it has the ability to understand and anticipate customer needs, new technologies, new markets, new products and the strengths and weaknesses of competitors. Zahra and George (2002) review previous studies related to absorptive capacity and find a significant positive relationship between absorptive capacity and innovation, since these factors work together to establish the organisation's competitive advantage. Nieto and Quevedo (2005) also found that absorptive capacity determines innovative effort.

In addition, absorptive capacity enables the firm to improve, expand and use existing internal learning capacities, as it favours the integration of internal and external knowledge. Therefore, researchers have increasingly highlighted the firm's necessity to complement internal learning capacity with absorptive capacity development (e.g., Soo et al., 2007; Haro-Domínguez et al., 2007). However, the dependence relationship between internal learning capacity and absorptive capacity seems no to be unidirectional. In this vein, Harabi (1995) points out that access by a firm to knowledge generated outside is not automatic and costless. So, this means that a firm is unable to absorb and apply externally available knowledge passively (Cohen and Levinthal, 1990). Internal learning capacity creates cultural patterns and a communication system open to change and learning together with an internal knowledge base that facilitates absorptive capacity (Cohen and Levinthal, 1990; Lane and Lubatkin, 1998).

Caloghirou et al. (2004) empirically investigate the extent to which the existing internal learning capabilities of firms and their interaction with external sources of knowledge affect their level of innovativeness. Their research findings show that some capabilities result from a prolonged process of investment and knowledge accumulation within firms. Authors such us Cassiman and Veugelers (2006) and Arora and Gambardella (1994) also prove the importance of internal learning for external sourcing empirically.

Taking into account the previous issues, and according to the conceptualisation of organisational learning (see Section 2.1), we can affirm that in industries in which knowledge and know-how is critical, the firm's innovation capacity depends on how well the firm can enhance its own knowledge base by both internally creating knowledge and 
obtaining knowledge from an outside source. The mutual dependence of internal learning capacity and absorptive capacity suggest the following hypothesis:

H1 Internal learning capacity and absorptive capacity have a joint effect on innovation capacity.

\subsection{Innovation capacity and performance}

Earlier literature on innovation has empirically studied and tested the direct and positive relationship between innovation capacity and performance (e.g., Hult et al., 2004; Tuominen and Hyvönen, 2004; García-Morales et al., 2007). According to these theories, organisations that have high innovation capabilities are more capable of creating 'isolating mechanisms' to ensure that knowledge of the innovation is not available to competitors (Chen et al., 2009). These mechanisms protect profit margins and generate significant benefits for the first movers (Ferrier et al., 1999). Specifically, García-Morales et al. (2007) empirically show that firms with greater innovation capacities, with independence of their organisational size, obtain superior responses from the environment and the necessary capacities to increment their business performance. In light of the above considerations, a second hypothesis may be outlined in the following terms:

H2 Innovation capacity has a positive influence on business performance.

\subsection{Internal learning capacity, absorptive capacity and performance}

According to studies such as those by Srivardhanaa and Pawlowski (2007) and Zahra and George (2002), although knowledge accumulation activities are important to renew the firm's knowledge stock and to avoid competence traps, these activities per se do not guarantee the obtaining of competitive advantage. In this vein, authors such us Hult et al. (2004) empirically demonstrate that learning activities have an indirect effect on business performance through the innovation capacity. According to these authors, the organisational efforts to create knowledge and to study the external market are not translated into economic rents, unless firms have developed certain innovation capacity in products and processes. Thus, both the internally created knowledge and the externally acquired knowledge should follow multiple and iterative paths, before the firm could successfully apply this knowledge to the obtaining of greater economic rent (Zahra and George, 2002). Therefore, we posit the following hypothesis:

H3 The complementary effect of both internal learning capacity and absorptive capacity on business performance is mediated by innovation capacity.

\section{Empirical analysis}

\subsection{Data}

The empirical validation of the measurement model was undertaken using a database of all Spanish industrial firms, with the exception of the energy sector, registered in Spain's National Statistics Institute Central Company Directory. The sample size was established 
at 2,000 firms, to guarantee a maximum margin of error of \pm 2.2 with a confidence interval of $95.5 \%$. Units were selected on the basis of stratified random sampling. The stratification criteria considered were size and industry. The population was classified into 14 sectors according to three-digit SIC codes and into four size groups according to the European Union's definition of micro, small, medium and large firms. The sample allocation procedure adopted in each group was that of optimal allocation. Within each group, the selection of units to be studied until the allocated size was reached was based on simple random sampling.

Data were obtained from questionnaires consisting of six sections and 127 questions. Information was provided on the firm's characteristics, senior managers' views on the general and competitive environment, their corporative and competitive strategies, growth and internationalisation strategy, organisational design, technological and production system, human resources, distinctive competencies portfolio, economic-financial results and their competitive position and commercial results in the national and international markets ${ }^{1}$. The information was gathered through selfadministered electronic questionnaires and provided by the firm's managing director or the chief executive (CEO or president). Field work was undertaken between February and May 2007. The final number of firms that completed the questionnaire was 952, giving a response rate of $47.6 \%$.

\subsection{Statistical techniques}

Confirmatory factor analysis (CPA) was carried out to demonstrate the psychometric properties of reliability, validity and dimensionality of the proposed theoretical model, following Bagozzi (1981) and Jöreskog (1969). The CPA was run using structural equations modelling (Anderson and Gerbing, 1982; Hair et al., 1998). The parameters were estimated using the maximum likelihood method with robust estimators, recommended by Satorra and Bentler (1994), to alleviate the requirements of normality. The EQS 6.0 statistical program (Bentler, 1995) was used to estimate the structural equations model.

\subsection{Measurement variables}

The increasing proliferation of multidimensional measurement scales is accompanied by the use of classification scales allowing the judgement and experience of managers to be expressed in subjective measures. Managerial self-evaluation of the firm's situation is growing as a way of measuring firms' resources and capabilities, since various studies demonstrate that they are convergent measurements with equivalent objective indicators (Camisón, 2005). This study uses Likert-type self-evaluation scales, which reflect managers' perception of the strength of the firm's capacity to value, identify, acquire assimilate, transform and apply new external knowledge, for each of the attributes of the construct as compared with their competitors in the industry. This procedure also has precedents in the distinctive competencies literature (e.g., Camisón, 2005; Camisón and Forés, 2009). Specifically, this study uses scales of five points, where 1 is 'much worse than our competitors', 3 is 'on an average with our competitors' and 5 is 'much better than our competitors'. The Appendix includes the scales dimensions and definition of the items. 
Care must be taken to avoid the risk of bias (automatic, carelessly considered responses) implicit in a non-neutrally designed questionnaire, as is the case when all the items are positively drafted. To a certain extent, this problem is consubstantial with resources-based approach, since we always define distinctive capabilities as sources of competitive advantage, and to do this we must measure them in terms of increasing strength vis-à-vis the competitors. In this study, in order to avoid the 'robot effect' in responses, we opted for a control process that consisted of formulating certain items inversely (see Appendix).

\subsubsection{Organisational learning}

According to the previous theoretical conceptualisation, we consider organisation learning capacity as a latent factor comprising both internal learning capacity and absorptive capacity. The final scale is presented in Appendix (see Table A1).

- Internal learning capacity. We conceptualised internal learning capacity as a multidimensional construct with two dimensions: managerial commitment and systems perspective. To measure these dimensions we use most of the items proposed by Jerez-Gómez et al. (2005) and some items derived from the analysis of the main scales in the literature (e.g., Garvin, 1993; Tannenbaum, 1997; Goh and Richards, 1997; Kontoghiorghes et al., 2005; Templeton et al., 2002).

- Absorptive capacity. Starting from the conceptualisation of the construct carried out above and in line with Zahra and George's (2002) definition, we consider absorptive capacity as a third-order latent construct formed by two dimensions: PACAP and RACAP. In turn, PACAP is a second-order factor consisting of two further subdimensions: knowledge acquisition capacity and knowledge assimilation capacity. On the other hand, RACAP, defined as another second-order factor, comprises the subdimensions of knowledge transformation and application or exploitation. The attributes selected to operationalise each dimension are justified on the base of a review of the main instruments proposed in the literature

(e.g., Szulanski, 1996; Lane et al., 2001; Vinding, 2006; Jansen et al., 2005; Tu et al., 2006).

\subsubsection{Innovation capacity}

An examination of the empirical literature published on innovation during the last decades reveals that firms' innovation has often been captured through proxies from the input (R\&D investment or effort) and the output perspectives (number of new products, processes and practices it generates in a given period), depending on the object of the study (Smith et al., 2005). One of the most prevalent measurement approaches consists of using binary indicators (i.e., presence or absence of product and/or process innovations during a specific time period). Such dichotomous measures allow the profiling of two categories of firms, namely, innovators and non-innovators.

However, recent researchers analyse organisations' innovation using reliable valid measurement scales, related to the innovator's behaviour, strategies and more recently, to the innovation capacities of firms (García-Morales et al., 2007; Liao et al., 2007). Building on these studies, we developed an ex novo scale to measure the innovation capacity, justified on the base of a review of the main instruments proposed in the 
literature (see Table A2 in Appendix). According to the conceptualisation of the construct, we considered innovation capacity as a second-order latent construct formed by two dimensions: process innovation and product innovation.

\subsubsection{Business performance}

We defined the construct as unidimensional and latent, inferred from four items that estimate the firm's economic performance. The final scale is presented in Appendix (see Table A3), with a definition of each item.

\subsubsection{Control variables}

We controlled for three variables related to internal and external aspects of the organisation that influence a firm's innovation capacity. The two internal factors are size and age, whereas the external factor is the industry to which the firm belongs. Size was measured as the amount of employees. Age was calculated considering the firm's year of establishment. Finally, firm's industry was measured with the industrial sector which firms belong to (between 18 industrial sectors identified with SIC two digits).

Table 1 shows the descriptive statistics and correlations of the study variables.

Table 1 Means, standard deviations and correlations between variables

\begin{tabular}{|c|c|c|c|c|c|c|c|c|c|c|c|c|c|c|c|c|c|c|}
\hline & Variable & Mean & $\mathrm{SD}$ & 1 & 2 & 3 & 4 & 5 & 6 & 7 & 8 & 9 & 10 & 11 & 12 & 13 & 14 & 15 \\
\hline 1 & $\alpha$ & & & 1.00 & & & & & & & & & & & & & & \\
\hline 2 & ILC & 3.62 & 0.52 & & 1.00 & & & & & & & & & & & & & \\
\hline 3 & $\mathrm{MC}$ & 3.67 & 0.52 & 0.74 & $0.91^{* *}$ & 1.00 & & & & & & & & & & & & \\
\hline 4 & $\mathbf{S P}$ & 3.58 & 0.61 & 0.69 & $0.93^{* *}$ & $0.6^{* *}$ & 1.00 & & & & & & & & & & & \\
\hline 5 & АCAP & 3.20 & 0.61 & 0.85 & $0.32^{* *}$ & $0.34^{*}$ & $0.25^{* *}$ & 1.00 & & & & & & & & & & \\
\hline 6 & PACAP & 3.19 & 0.63 & 0.80 & $0.32^{* *}$ & $0.33^{* *}$ & $0.25^{* *}$ & $0.95^{* *}$ & 1.00 & & & & & & & & & \\
\hline 7 & RACAP & 3.20 & 0.65 & 0.70 & $0.28 * *$ & $0.31^{* *}$ & $0.22^{* *}$ & $0.95^{* *}$ & $0.80^{* *}$ & 1.00 & & & & & & & & \\
\hline 8 & $\mathrm{AC}$ & 3.14 & 0.71 & 0.77 & $0.22^{* *}$ & $0.26^{* *}$ & $0.15^{* *}$ & $0.87^{* * *}$ & $0.91^{* *}$ & $0.74 * *$ & 1.00 & & & & & & & \\
\hline 9 & AS & 3.25 & 0.68 & 0.79 & $0.36^{* *}$ & $0.35^{* *}$ & $0.31^{* *}$ & $0,85^{* *}$ & $0.90^{* *}$ & $0.71^{* *}$ & $0.65^{* *}$ & 1.00 & & & & & & \\
\hline 10 & $\mathbb{R}$ & 3.16 & 0.67 & 0.75 & $0.28^{* *}$ & $0.30^{k *}$ & $0.21^{* *}$ & $0.90^{\text {sk }}$ & $0 . T^{* * *}$ & $0.92^{* *}$ & $0.70^{4 *}$ & $=0.72^{\text {** }}$ & 1.00 & & & & & \\
\hline 11 & $\mathrm{AP}$ & 3.24 & 0.73 & 0.72 & $0.25^{* *}$ & $0.27 * *$ & $0.19^{* *}$ & $0.87^{* *}$ & $0.71^{* *}$ & $0.93^{* *}$ & $0.68^{* *}$ & $0.61^{* *}$ & $0.72^{* *}$ & 1.00 & & & & \\
\hline 12 & INCAP & 3.51 & 0.60 & 0.60 & $0.45^{* *}$ & $0.43^{* *}$ & $0.40^{* \%}$ & $0.53^{* *}$ & $0.52^{* *}$ & $0.50 \%$ & $0.40^{2 * 3}$ & $0.54^{* * *}$ & $0.45^{* *}$ & $0.47^{* * *}$ & 1.00 & & & \\
\hline 13 & PRD & 3.51 & 0.62 & 0.58 & $0.43^{* *}$ & $0.41^{* *}$ & $0.38^{* *}$ & $0.51^{\text {** }}$ & $0.51^{* *}$ & $0.47 * *$ & $0.40^{\text {kek }}$ & $0.53^{* * *}$ & $0.42^{*}$ & $0.45^{* *}$ & $0.92^{* *}$ & 1.00 & & \\
\hline 14 & PRC & 3.51 & 0.60 & 0.55 & $0.40^{* *}$ & $0.39 \%$ & $0.35^{* *}$ & $0.48^{* *}$ & $0.45^{* *}$ & $0.46^{* *}$ & $0.34^{*}$ & $0.44^{* *}$ & $0.4^{* *}$ & $0.42 * *$ & $0.93^{* *}$ & $0.72^{* *}$ & 1.00 & \\
\hline 15 & $\mathrm{OP}$ & 3.25 & 0.60 & 0.32 & $0.12^{*}$ & $0.13^{* *}$ & $0.12 *$ & $0.36^{* *}$ & $0.31^{* *}$ & $0.37 * *$ & $0.29^{* *}$ & $0.22^{* * *}$ & $0.36^{* *}$ & $0.34 * *$ & $0.29^{* *}$ & $0.28^{* * *}$ & $0.27^{\text {** }}$ & 1.00 \\
\hline
\end{tabular}

Comment: Author: Please provide a word version of Table 1 which we can format using Inderscience guidelines for tables..

Notes: ${ }^{*} \mathrm{p}<0.05 ; * * \mathrm{p}<0.01 ; \mathrm{OL}=$ organisational learning; ILC = internal learning capacity; $\mathrm{MC}=$ managerial commitment; $\mathrm{SP}=$ systems perspective; ACAP = absorptive capacity; PACAP = potential absorptive capacity; RACAP = realised absorptive capacity; AC = acquisition capacity; $\mathrm{AS}=$ assimilation capacity; $\mathrm{TR}=$ transformation capacity; $\mathrm{AP}=$ application capacity; INCAP = innovation capacity; $\mathrm{PRD}=$ product innovation; $\mathrm{PRC}=$ process innovation; and $\mathrm{OP}=$ organisational performance. 
Table 2 Measurement model properties

\begin{tabular}{|c|c|c|c|c|}
\hline Factors $^{a}$ & $\begin{array}{c}\text { Standardised } \\
\text { loadings }\end{array}$ & $t$-value $e^{c}$ & $R^{2}$ & $\begin{array}{c}\text { Joint } \\
\text { reliability }\end{array}$ \\
\hline Organisational learning & & & 0.478 & 0.500 \\
\hline Internal learning capacity & $0.692^{\mathrm{b}}$ & & & 0.928 \\
\hline Systems perspective & $0.956^{\mathrm{b}}$ & & 0.914 & 0.700 \\
\hline SP1 & $0.639^{\mathrm{b}}$ & & 0.408 & \\
\hline SP2 & 0.600 & 7.577 & 0.361 & \\
\hline SP3 & 0.691 & 10.088 & 0.478 & \\
\hline SP4 & 0.537 & 8.549 & 0.288 & \\
\hline SP5 & 0.554 & 8.700 & 0.306 & \\
\hline Managerial commitment & 0.999 & 5.409 & 0.999 & 0.676 \\
\hline $\mathrm{MC} 1$ & $0.660^{\mathrm{b}}$ & & 0.435 & \\
\hline $\mathrm{MC} 2$ & 0.542 & 8.076 & 0.294 & \\
\hline $\mathrm{MC} 3$ & 0.536 & 8.200 & 0.287 & \\
\hline MC4 & 0.443 & 6.443 & 0.196 & \\
\hline MC5 & 0.488 & 8.348 & 0.238 & \\
\hline MC6 & 0.570 & 7.980 & 0.324 & \\
\hline Absorptive capacity & 0.531 & 1.850 & 0.303 & 0.953 \\
\hline PACAP & $1.000^{\mathrm{b}}$ & & 1.000 & 0.866 \\
\hline RACAP & 0.981 & 3.653 & 0.963 & 0.955 \\
\hline Acquisition capacity & $0.955^{\mathrm{b}}$ & & 0.913 & 0.646 \\
\hline $\mathrm{AC} 1$ & $0.575^{\mathrm{b}}$ & & 0.564 & \\
\hline $\mathrm{AC} 2$ & 0.683 & 18.871 & 0.467 & \\
\hline $\mathrm{AC} 4$ & 0.751 & 24.968 & 0.564 & \\
\hline Assimilation capacity & 0.963 & 2.558 & 0.927 & 0.670 \\
\hline AS1 & $0.702^{b}$ & & 0.492 & \\
\hline AS2 & 0.579 & 10.451 & 0.336 & \\
\hline AS3 & 0.629 & 11.675 & 0.396 & \\
\hline AS4 & 0.599 & 11.829 & 0.359 & \\
\hline Transformation capacity & $1.000^{\mathrm{b}}$ & & 1.000 & 2.939 \\
\hline TR1 & $0.694^{\mathrm{b}}$ & & 0.481 & \\
\hline TR3 & 0.562 & 10.690 & 0.315 & \\
\hline TR4 & 0.702 & 11.968 & 0.493 & \\
\hline TR5 & 0.733 & 14.030 & 0.537 & \\
\hline Application capacity & 0.983 & 16.668 & 0.965 & 0.625 \\
\hline AP2 & $0.625^{\mathrm{b}}$ & & 0.391 & \\
\hline AP3 & 0.677 & 3.292 & 0.459 & \\
\hline AP4 & 0.646 & 3.243 & 0.417 & \\
\hline
\end{tabular}

Notes: $\chi^{2}=824.055 ;$ d.f. $=759 ; p=0.05$

${ }^{\text {a }}$ See Appendix for items descriptions.

${ }^{\mathrm{b}}$ Parameter equal to one to determine the scale of the latent variable.

${ }^{\mathrm{c}}$ Absolute t-values greater than 1.645 are one-tail significant at $5 \%$. 
The complementary effect of internal learning capacity

Table 2 Measurement model properties (continued)

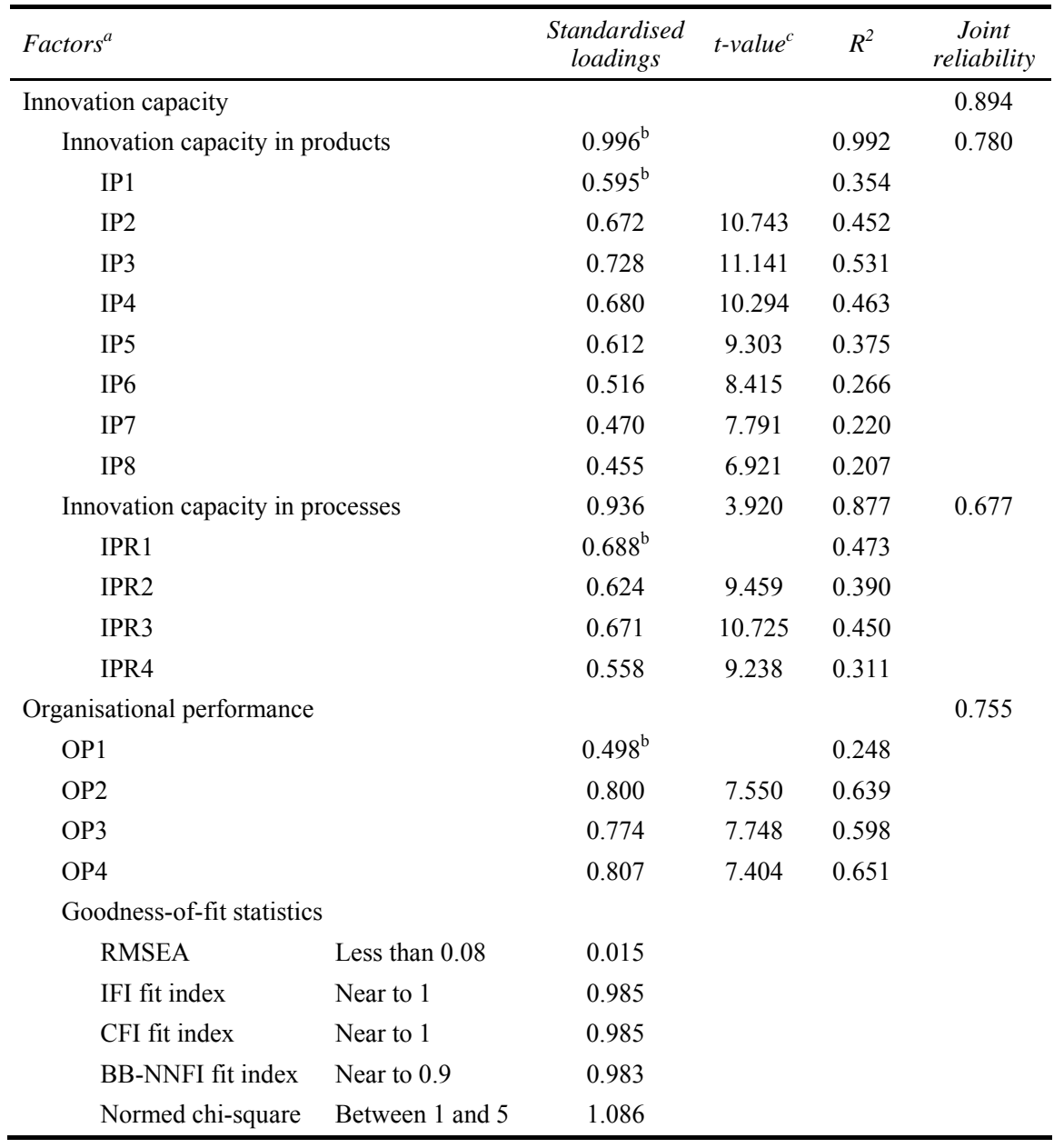

Notes: $\chi^{2}=824.055 ;$ d.f. $=759 ; \mathrm{p}=0.05$.

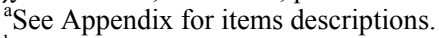

${ }^{\mathrm{b}}$ Parameter equal to one to determine the scale of the latent variable.

${ }^{\mathrm{c}}$ Absolute t-values greater than 1.645 are one-tail significant at $5 \%$.

\subsection{Results}

\subsubsection{Measurement model}

To develop a measurement model, we ran a joint CPA for all latent factors. CPAs resulted in certain modifications to the initial model in order to achieve a good fit; namely, items AC3, AS5, AS6, TR2 and AP1 from the initial scale of absorptive capacity were eliminated following the instructions of the LMTEST. We studied the goodness of fit of the factor models on the basis of the estimation technique proposed by Hair et al. 
(1998). Specifically, we verified absolute goodness-of-fit with the root mean square error of approximation (RMSEA), incremental goodness-of-fit with the incremental fit index (IFI), the comparative fit index (CFI) and the Bentler-Bonnett non-normed fit index (BB-NNFI) and parsimonious goodness-of-fit with the normed chi-square (NC) (Table 1). The goodness of fit statistics show the dimensionality of the constructs we proposed.

To estimate the reliability of the latent constructs, we calculated the composite reliability index, which was greater than 0.60 , the minimum value recommended by Churchill (1979), for all the factors (Table 2) with the exception of organisational learning that reaches a value of 0.50 . Considering the exploratory nature of this study, and the fact that organisational learning construct is a fourth-order latent factor, we have decided not to reformulate this construct.

To calculate the reliability of the individual items, we used the $\mathrm{R}^{2}$ statistic (Hair et al., 1998). The standardised loadings are higher than the required minimum value of 0.5 (Anderson and Gerbing, 1982; Hair et al., 1998) except in five items (M4 $=0.443$, M5 $=0.488$, IP7 $=0.470$, IP8 $=0.455$, OP1 $=0.498$, which came very close to the minimum level; we, therefore, decided not to eliminate them so as not to weaken the definition of the respective constructs domains.

We evaluated discriminant validity from the correlations matrix between each of the model's dimensions. The correlation between the dimensions of the same construct was greater than their correlations with the other dimensions and constructs with which they were theoretically related, confirming the discriminant validity of the model (see Table 2). The convergent validity was tested in three ways by the:

1 fit of the model (BB-NNFI)

2 standardised factor loadings (minimum of 0.50)

3 the significance of factor loadings (Anderson and Gerbing, 1982).

Considering the last test, we found that all loadings were statistically significant $(\mathrm{t} \geq 1.96$; $\alpha=0.5$ ).

Finally, we verified concurrent validity for demonstrations relating a measurement to other criteria assessed simultaneously or which exist at the same time. A generally accepted way of checking the concurrent validity is by its correlation with some objective measures included in the survey, which can be considered as criterion variables for some scale indicators. This procedure also allows verifying whether the measurement of capabilities on the basis of managers' perceptions is convergent with the objective measurement on the basis of quantitative data. The comparison was made for the items AP4, which was correlated with the number of patents; item TR1, which was correlated with the number of information technology-based innovations introduced by the firm; item AC2, which was correlated with the number of technological cooperation agreements established by the firm; and item AS5, which was correlated with the percent of firm personnel involved in external knowledge-based activities. Results indicate that Pearson's correlation coefficients are positive $(0.45,0.34,0.37$ and 0.30 , respectively) and statistically significant $(\mathrm{p}<0.01)$.

A key problem in evaluating capabilities is the preservation of objectivity. One basic reason for the lack of confidence in the objectivity of managerial perceptions of the firm's capabilities lies in the broad margin of variation, which may lead to very serious evaluation errors [Grant, (1991), p.121]. Concurrent validity for the scales proposed by 
measuring internal learning capacity, absorptive capacity, innovation capacity and business performance would lead to the conclusion that the risk of bias is not high, unlike the correlation between subjective and objective measures.

The methodology used to validate the measurement scales is also of particular interest to distinguish source of bias in the measurement caused by a single respondent approach from 'true' relationships between constructs in latent variables. SEM allows concepts that are not directly observable to be examined; it allows various multiple dependence relationships to be estimated simultaneously with statistical efficiency; and it allows error in estimating multiple dependence relationships, caused by imperfect measurement of latent variables, to be directly incorporated (Hair et al., 1998).

\subsubsection{Structural model}

The hypotheses were jointly assessed by the structural model (Figure 1). The model is over-identified (degrees of freedom $>0$ ) and has adequate fit indexes (RMSEA $=0.012$, IFI $=0.990, \mathrm{CFI}=0.990, \mathrm{BB}-\mathrm{NNFI}=0.989, \mathrm{NC}=1.052$,$) . All the parameters were$ significant at the 0.05 level, the factor loadings were greater than the value 0.50 except in three items $(\mathrm{M} 4=0.438$, M5 $=0.496$, IP7 $=0.479$, IP8 $=0.493)$, which came very close to the minimum level. The composite reliabilities also exceeded 0.60. The measurement model, therefore, fits the data with reliable and valid measurement indicators. The hypothesised model almost explained a $20 \%$ of the variance in business performance $(\mathrm{R}=0.183)$.

Considering the control variables, age and industry did not significantly affect business performance. The non-significant effect of age may reflect inconclusiveness of arguments in their relationship with business performance. We controlled for industry because exchange processes, knowledge acquisition and relationship outcomes are expected to vary by industry (Lane and Lubatkin, 1998; Yli-Renko et al., 2001). However, our finding of a lack of significant influence of industry on business performance is not without precedence (e.g., Chen, 2004; Camisón, 2004). Unlike age and industry, size obtains a significant path coefficient $(0.226, \mathrm{p}<0.01)$. This result confirms that performance is positively and significantly related to performance in large firms. Large firms usually have greater economic resources and stronger possibilities for knowledge creation and innovation (García-Morales et al., 2007).

Hypothesis 1 that predicted that internal learning capacity and absorptive capacity have a joint effect on innovation capacity is supported $(\beta=0.964, p<0.05$, Figure 1$)$. Hypothesis 2, which proposed that innovation capacity has a positive relationship with business performance, was also supported $(\beta=0.354, p<0.001$, Figure 1$)$. Hypothesis 3 that predicted that the complementary effect of both internal learning capacity and absorptive capacity on business performance is mediated by innovation capacity was supported too $(\beta=0.341, \mathrm{p}<0.05$, Figure 1$)$. 
Figure 1 Conceptual model

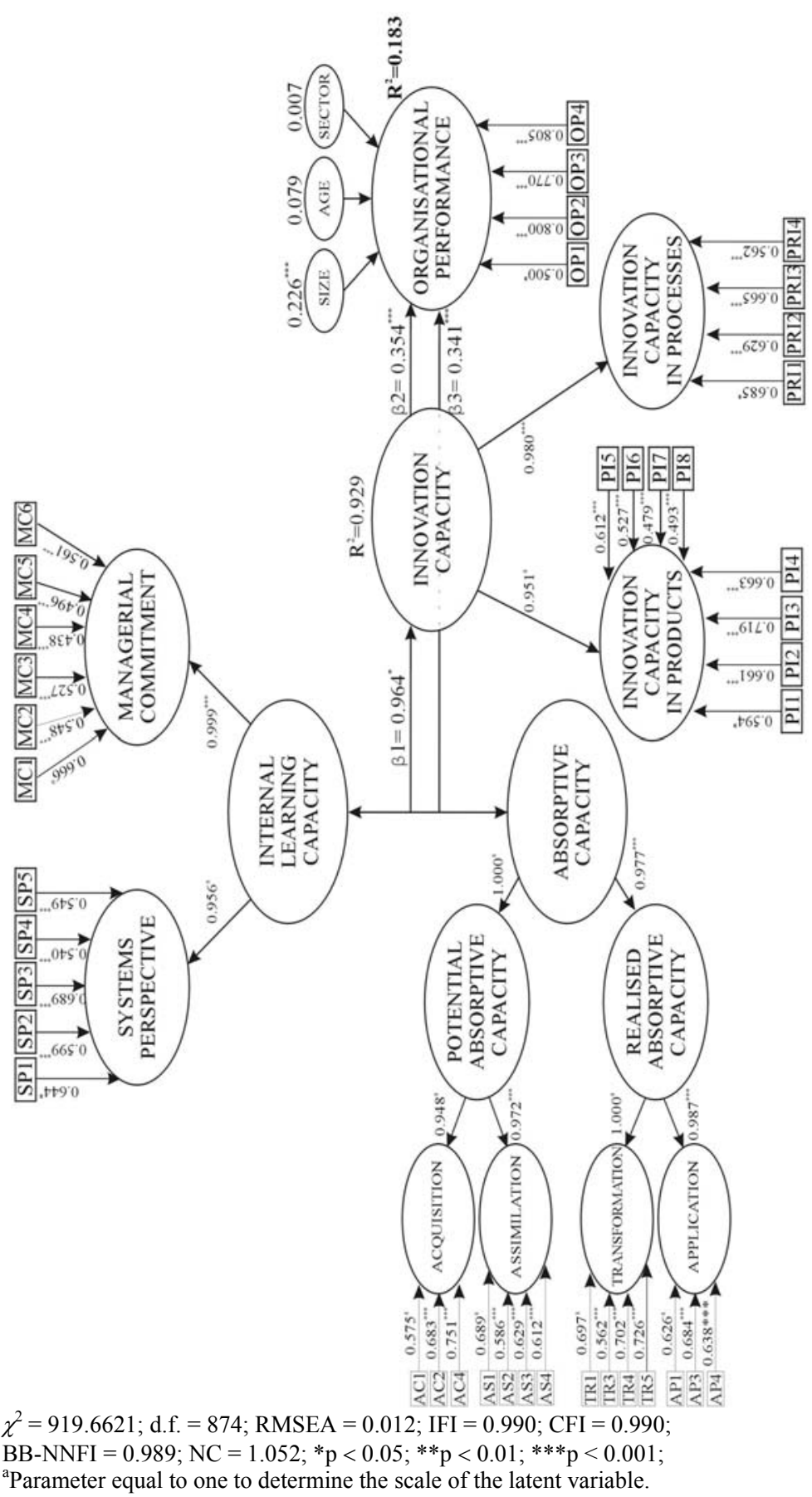




\subsubsection{Alternative model evaluation}

The hypothesised model (Figure 1) is a fully mediated model (Fairchild and Mackinnon, 2009). Following the recommendations for the evaluation of causal models in management research (Piccolo and Colquitt, 2006; Rindova et al., 2005), we conducted additional analyses to test the validity of a non-mediated model and a partially mediated model. Both the non-mediated model (RMSEA $=0.032$, IFI $=0.924, \mathrm{CFI}=0.923$, $\mathrm{BB}-\mathrm{NNFI}=0.916, \mathrm{NC}=1.390)$ and the partially mediated (RMSEA $=0.020$, $\mathrm{IFI}=0.969, \mathrm{CFI}=0.968, \mathrm{BB}-\mathrm{NNFI}=0.965, \mathrm{NC}=1.160)$ fit the data well.

Further chi-squares in non-mediated model $\left(\Delta \chi^{2}=293.034, p<0.001\right)$ and in partially mediated model $\left(\Delta \chi^{2}=92.643, \mathrm{p}<0.001\right)$ increased with respect to the conceptual model proposed (Figure 1) and differences are significant at the 0.05 level, confirming that the hypothesised model represents a better fit than both alternative models (Rindova et al., 2005).

\section{Discussion and conclusions}

Improving the firm's innovation capacity has become an important top management concern. The generation and adoption of innovation is a mean for organisational change to facilitate realising the firm's performance goals, especially under the conditions of intense competition, rapidly changing market, scarce resources and customer and public demand for higher quality and better products and services (Damanpour et al., 2009; Jansen et al., 2006).

More and more studies have emphasised the extent to which innovation involves the combination of firm's internal learning and absorptive capacities. A firm's internal learning capacity allows the generation of new knowledge, the developing of firm's core competences, the control and understanding of the knowledge development process, and the obtaining of more difficult-to-imitate innovations. Alternatively, absorptive capacity is required for the firm to access to knowledge and resources that cannot be generated internally, develop a diverse knowledge base, upgrade their core competences and remain flexible. In this vein, the essential purpose of this study was to explicitly address the joint effect of both organisational learning capacities on innovation capacity and business performance. To empirically test the hypotheses derived from the theoretical review, we developed a model of structural equations using EQS 6.1 program.

Our results are consistent with the importance of organisational learning capacities on innovation needed to face the dynamic environment and to sustain competitive advantage. The empirical results are consistent with studies such us those by Pérez López et al. (2005) and Calantone et al. (2002). This study also provides evidence on the importance of innovation capacity on business performance. This finding is supported by the literature on organisational innovation and learning (Grant, 1996; Kogut and Zander, 1992; Hult et al., 2004; García-Morales et al., 2007). The research results also confirmed that innovation capacity is a fully mediating variable on the relationship between organisational learning capabilities and business performance. This means that unless firms translates knowledge generated internally or acquired from the firm's external environment into new products or processes, superior performance will not be obtained.

The completely mediating model indicates that innovation capacity is a key factor in improving firm's business performance. However, businesses should recognise that 
organisational learning improves this innovation capacity and they should not neglect the importance of both internal learning capacity and absorptive capacity development in the firm. Therefore, innovation management requires a tight integration of internal and external learning capacities within the firm's innovation process to capture the positive effects that each knowledge generating activity has on the marginal return of the other.

Apart from making a significant contribution to the dynamic capacities literature by empirically exploring the relationships between organisational learning capabilities, innovation capacity and business performance, this research also advances the conceptual distinction between these three constructs that lies behind this theoretical model. In this vein, we create and validate two scales for measuring the constructs organisational learning and innovation capacity. The results obtained from the CPA for all measurement instruments confirm that they meet the psychometric requirements of dimensionality, validity and reliability, and as such, they represent interesting tools for further development in future research.

\subsection{Future research}

Our work is intended as an attempt to show that internal learning capacity and absorptive capacity are fundamentally interrelated with the process of change and innovation, and that innovation capacity is a fully mediating variable between organisational learning and business performance, but obviously more work is needed before we will achieve a complete understanding of the relationship between organisational learning and innovation capacity and business performance. In this vein, the analysis of the results obtained for the construct organisational learning (Table 2) shows that, although the literature suggest a strong correlation between internal learning capacity and absorptive capacity, conceptually they do not have to always correlate and other researchers may observe lower correlations if the scale is administrated in a different context.

Therefore, future studies should examine the direction of the relationships between internal learning capacity, absorptive capacity and their specific effects on innovation capacity and performance. Authors such as Rosenkop and Nerkar (2001) and Phene et al. (2006) have attempted to refine the broader arguments relating external knowledge to innovation by delineating the type of external knowledge and the kind of innovation. Extending these studies to the internal learning types and considering the innovation process in distinct phases (see Kessler et al., 2000) and separated in other classifications of innovation capacity (e.g., management innovation; incremental versus radical innovation) would provide the literature with more consistency.

\subsection{Limitations}

This study is subject to a number of limitations that might also constitute opportunities for future research. Firstly, the responses are subject to interpretation by individual managers. Thus, only subjective information from the questionnaire for measuring company results was taken into account. Although this kind of information is commonly used in studies, it is necessary to introduce other measures from objective sources to replicate this result and avoid social desirability bias.

Second, the ex novo measurement scales for absorptive capacity and innovation capacity have not been validated in the previous literature, so they are considered as exploratory scales. Regarding the generalisation of the results of this study, the fact that 
the data have been collected from a multi-industry sample makes the findings robust. However, this research was conducted using a sample of Spanish firms, and as such, we should be cautious about generalising from the results.

Finally, the data used in this study is cross-sectional. The cross-sectional nature of the research into a series of dynamic capacities (organisational learning, absorptive capacity and innovation capacity) allows us to analyse only a specific situation in the organisations at one time, not their behaviour over time. Although the approach used reduces this problem by means of measurement scales with items that reflect dynamic characteristics, it is clear that in order to establish the causal linkages of the model one needs longitudinal data. Our results should therefore be interpreted as association between variables and not in terms in causality. There are therefore many avenues for future studies to extend and refine this research framework.

\section{Acknowledgements}

The authors are grateful for the financial support from the Generalitat Valenciana (projects ref. GV/2007/075, ARVIV/2007/077 and GVPRE/2008/054), as part of the Plan 2007 for Research Promotion UJI-Fundació Bancaixa (project ref. P1-1B2007-20) and Program 2008 of Grants for Economic Research from the Valencian Institut for Economic Research IVIE.

\section{References}

Anderson, J.C. and Gerbing, D.W. (1982) 'Some methods for respecifying measurement models to obtain unidimensional constructs measures', Journal of Marketing Research, Vol. 19, pp.453-460.

Arora, A. and Gambardella, A. (1994) 'Evaluating technological information and utilizing it: scientific knowledge, technological capability and external linkages in biotechnology', Journal of Economic Behaviour and Organization, Vol. 24, pp.91-114.

Bagozzi, R.P. (1981) 'Evaluating structural equations models with unobservable variables and measurement error: a comment', Journal of Marketing Research, Vol. 18, pp.375-381.

Bentler, P.M. (1995) EQS Structural Equations Program Manual, Multivariate Software, Encino, CA.

Bierly, P., Damanpour, F. and Santoro, M. (2009) 'The application of external knowledge: organizational conditions for exploration and exploitation', Journal of Management Studies, Vol. 3, pp.481-509.

Bierly, P.E. and Chakrabarti, A. (1996) 'Technological learning, strategic flexibility and new product development in the pharmaceutical industry', IEEE Transactions on Engineering Management, Vol. 43, No. 4, pp.368-380.

Bontis, N., Crossan, M.M. and Hulland, J. (2002) 'Managing an organizational learning system by aligning stocks and flows', Journal of Management Studies, Vol. 39, No. 4, pp.437-469.

Boynton, A.C., Zmud, R.W. and Jacobs, G.C. (1994) 'The influence of IT management practice on IT use in large organizations', MIS Quarterly, Vol. 18, No. 3, pp.299-318.

Calantone, R.J., Cavusgil, S.T. and Zhao, Y. (2002) 'Learning orientation, firm innovation capability and firm performance', Industrial Marketing Management, Vol. 31, No. 6, pp.515-524. 
Caloghirou, Y., Kastelli, I. and Tsakanikas, A. (2004) 'Internal capabilities and external knowledge sources: complements or substitutes for innovative performance', Technovation, Vol. 24, No. 1, pp.29-39.

Camisón, C. (2004) 'Shared, competitive and comparative advantages: a competence-based view of industrial-district competitiveness', Environment and Planning A, Vol. 36, No. 12, pp.2227-2256.

Camisón, C. (2005) 'On how to measure managerial and organizational capabilities', Management Research, Vol. 3, No. 1, pp.27-48.

Camisón, C. and Forés, B. (2009) 'Knowledge absorptive capacity: new insights for its conceptualization and measurement', Journal of Business Research, in press.

Cassiman, B. and Veugelers, R. (2006) 'In search of complementarity in innovation strategy: internal R\&D and external knowledge acquisition', Management Science, Vol. 52, pp.68-82.

Chen, C.J. (2004) 'The effects of knowledge attribute, alliance characteristics and absorptive capacity on knowledge transfer performance', $R \& D$ Management, Vol. 34, No. 3, pp.311-321.

Chen, Y-S., Lin, M-J. and Chang, C-H. (2009) 'The positive effects of relationship learning and absorptive capacity on innovation performance and competitive advantage in industrial markets', Industrial Marketing Management, Vol. 38, pp.152-158.

Churchill, G.A. (1979) 'A paradigm for developing better measures of marketing constructs', Journal of Marketing Research, Vol. 16, pp.64-73.

Cohen, W.M. and Levinthal, D.A. (1989) 'Innovation and learning: the two faces of R\&D', The Economic Journal, Vol. 99, pp.569-596.

Cohen, W.M. and Levinthal, D.A. (1990) 'Absorptive capacity: a new perspective on learning and innovation', Administrative Science Quarterly, Vol. 35, pp.128-152.

Damanpour, F. and Gopalarkrishnan, S. (2001) 'The dynamics of the adoption of product and process innovations in organisations', Journal of Management Studies, Vol. 38, pp.45-65.

Damanpour, F. and Schneider, M. (2006) 'Phases of the adoption of innovation in organizations: effects of environment, organization and top managers', British Journal of Management, Vol. 17, pp.215-236.

Damanpour, F., Walker, R.M. and Avellaneda, C.N. (2009) 'Combinative effects of innovation types on organizational performance: a longitudinal study of public services', Journal of Management Studies, Vol. 46, No. 4, pp.650-675.

Day, G.S. (1994) 'The capabilities of market driven organizations', Journal of Marketing, Vol. 58, No. 5, pp.37-52.

De Clercq, D. and Dimov, D. (2008) 'Internal knowledge development and external knowledge access in venture capital investment performance', Journal of Management Studies, Vol. 45, No. 3, pp.585-612.

Fairchild, A. and Mackinnon, D.P. (2009) 'A general model for testing mediation and moderation effects', Journal Prevention Science, Vol. 10, No. 2, pp.87-99, Springer Netherlands.

Ferrier, W.J., Smith, K.G. and Grimm, C. (1999) 'The role of competitive action in market share erosion and industry dethronement: a study of industry leaders and challengers', Academy of Management Journal, Vol. 42, pp.372-388.

García-Morales, V., Ruiz-Moreno, A. and Llorens-Montes, F.J. (2007) 'Effects of technology absorptive capacity and technology proactivity on organizational learning, innovation and performance: an empirical examination', Technology Analysis \& Strategic Management, Vol. 19, No. 4, pp.557-558.

Garvin, D.A. (1993) 'Building a learning organisation', Harvard Business Review, July-August, pp.78-91.

Goh, S. and Richards, G. (1997) 'Benchmarking the learning capacity of organizations', European Management Journal, Vol. 15, No. 5, pp.575-583.

Grant, R.M. (1991) 'The resource-based theory of competitive advantages: implications for strategy formulation', California Management Review, Vol. 33, pp.114-135. 
Grant, R.M. (1996) 'Toward a knowledge-based theory of the firm', Strategic Management Journal, Vol. 17, pp.109-122.

Hair, J.F., Anderson, R.E., Tatham, R. and Black, W. (1998) Multivariate Data Analysis, Prentice Hall, Homewood.

Harabi, N. (1995) 'Appropriability of technical innovations an empirical analysis', Research Policy, Vol. 24, No. 6, pp.981-992.

Haro-Domínguez, M.C., Arias-Aranda, D., Llorens Montes, F.J. and Moreno, A.R. (2007) 'The impact of absorptive capacity on technological acquisitions engineering consulting companies', Technovation, Vol. 27, No. 8, pp.417-425.

Henderson, R.M. and Clark, K.B. (1990) 'Architectural innovation: the reconfiguration of existing product technologies and the failure of established firms administration', Science Quarterly, Vol. 35, pp.9-30.

Hitt, M.A., Hoskisson, R.E., Johnson, R.A. and Moesel, D.D. (1996) 'The market for corporate control and firm innovation', Academy of Management Journal, Vol. 39, pp.1084-1119.

Hult, T.M., Hurley, R.F. and Knight, G.A. (2004) 'Innovativeness: its antecedents and impact on business performance', Industrial Marketing Management, Vol. 23, No. 5, pp.429-438.

Jansen, J.J.P., Van Den Bosch, F.A.J. and Volberda, H.W. (2005) 'Managing potential and realized absorptive capacity: how do organizational antecedents matter?', Academy of Management Journal, Vol. 48, No. 6, pp.999-1015.

Jansen, J.J.P., Van den Bosch, F.A.J. and Volberda, H.W. (2006) 'Exploratory innovation, exploitative innovation and performance: effects of organizational antecedents and environmental moderators', Management Science, Vol. 52, pp.1161-1674.

Jerez-Gómez, P., Céspedes-Lorente, J. and Valle Cabrera, R. (2005) 'Organizational learning capability: a proposal of measurement', Journal of Business Research, Vol. 58, No. 6, pp.715-725.

Jöreskog, K.G. (1969) 'A general approach to confirmatory maximum likelihood factor analysis', Psychometrica, Vol. 34, pp.183-202.

Kahn, K.B. (2001) 'Market orientation, interdepartmental integration and product development performance', Journal of Product Innovation Management, Vol. 18, pp.314-323.

Kessler, E.H., Bierly, P.E. and Gopalakrishnan, S. (2000) 'Internal vs. external learning in new product development: effects of speed, costs and competitive advantage', R\&D Management, Vol. 30, No. 3, pp.213-224.

Kogut, B. and Zander, U. (1992) 'Knowledge of the firm, combinative capabilities and the replication of technology', Organization Science, Vol. 3, pp.383-397.

Kontoghiorghes, C., Awbre, S.M. and Feurig, P.L. (2005) 'Examining the relationship between learning organization characteristics and change adaptation, innovation and organizational performance', Human Resource Development Quarterly, Vol. 16, No. 2, pp.185-211.

Lane, P.J. and Lubatkin, M. (1998) 'Relative absorptive capacity and interorganizational learning', Strategic Management Journal, Vol. 19, pp.461-477.

Lane, P.J., Koka, B.R. and Pathak, S. (2006) 'The reification of absorptive capacity: a critical review and rejuvenation of the construct', Academy of Management Review, Vol. 31, No. 4, pp.833-863.

Lane, P.J., Salk, J.E. and Lyles, M.A. (2001) 'Absorptive capacity, learning and performance in international joint ventures', Strategic Management Journal, Vol. 22, pp.1139-1161.

Lawson, B. and Samson, D. (2001) 'Developing innovation capability in organisations: a dynamic capabilities approach', International Journal of Innovation Management, Vol. 5, No. 3, pp.377-400.

Liao, S-H., Fei, W-C. and Chen, C-C. (2007) 'Knowledge sharing, absorptive capacity and innovation capability: an empirical study of Taiwan's knowledge-intensive industries', Journal of Information Science, Vol. 20, pp.1-20. 
Nieto, M. and Quevedo, P. (2005) 'Absorptive capacity, technological opportunity, knowledge spillovers, and innovative effort', Technovation, Vol. 25, No. 10, pp.1141-1157.

Nonaka, I. (1994) 'A dynamic theory of organizational knowledge creation', Organization Science, Vol. 5, pp.14-37.

Pérez López, S., Montes Peón, J.M. and Vázquez Ordás, C. (2005) 'Organizational learning as a determining factor in business performance', The Learning Organisation: An International Journal, Vol. 12, No. 3, pp.227-245.

Phene, A., Fladmoe-Lindquist, K. and Marsh, L. (2006) 'Breakthrough innovations in the US biotechnology industry: the effects of technological space and geographic origin', Strategic Management Journal, Vol. 27, No. 4, pp.369-388.

Piccolo, R.F. and Colquitt, J.A. (2006) 'Transformational leadership and job behaviors: the mediating role of core job characteristics', Academy of Management Journal, Vol. 49, pp.327-340.

Prajogo, D.I. and Ahmed, P.K. (2006) 'Innovation stimulus and innovation capacity: integrating the human and technological sides of innovation management - an Australian study', $R \& D$ Management, Vol. 36, No. 5, pp.499-515.

Rindova, V.P., Williamson, I.O., Petkova, A.P. and Sever, J.M. (2005) 'Doing good or being known: an empirical examination of the dimensions, antecedents and consequences of organizational reputation', Academy of Management Journal, Vol. 48, No. 6, pp.1033-1049.

Rosenkopf, L. and Nerkar, A. (2001) 'Beyond local search: boundary-spanning, exploration and impact in the optical disc industry', Strategic Management Journal, Vol. 22, No. 4, pp.287-307.

Rush, H., Bessant, J. and Hobday, M. (2007) 'Assessing the technological capabilities of firms: developing a policy tool', R\&D Management, Vol. 37, No. 3, pp.221-236.

Satorra, A. and Bentler, P.M. (1994) 'Corrections to test statistics and standard error in covariance structure analysis', in A. Von Eye and C.C. Clogg (Eds.): Latent Variables Analysis: Applications for Developmental Research, pp.399-419, Sage Publications Ltd., Thousand Oaks, CA.

Schein, E.H. (1993) 'On dialogue, culture and organizational learning', Organizational Dynamics, Vol. 22, No. 2, pp.40-51.

Smith, K.G., Collins, C.J. and Clark, K.D. (2005) 'Existing knowledge, knowledge creation capability and the rate of new product introduction in high-technology firms', Academy of Management Journal, Vol. 48, pp.346-357.

Soo, C., Devinney, T.M. and Midgley, D.F. (2007) 'External knowledge acquisition, creativity and learning in organisational problem solving', International Journal of Technology Management, Vol. 38, Nos. 1/2, pp.137-159.

Srivardhanaa, T. and Pawlowski, S. (2007) 'ERP systems as an enabler of sustained business process innovation: a knowledge-based view', The Journal of Strategic Information Systems, Vol. 16, No. 1, pp.51-69.

Szulanski, G. (1996) 'Exploring internal stickiness: impediments to the transfer of best practice within the firm', Strategic Management Journal, Vol. 17, pp.27-43.

Tannenbaum, S.I. (1997) 'Enhancing continuous learning: diagnostic findings from multiple companies', Human Resource Management, Vol. 36, No. 4, pp.437-452.

Templeton, G.F., Lewis, B.R. and Snyder, C.A. (2002) 'Development of a measure for the organizational learning construct', Journal of Management Information Systems, Vol. 19, No. 2, pp.175-218.

Tu, Q., Vonderembse, M.A., Ragu-Nathan, T.S. and Sharkey, T. (2006) 'Absorptive capacity: enhancing the assimilation of time-based manufacturing practices', Journal of Operations Management, Vol. 24, No. 5, pp.692-710.

Tuominen, M. and Hyvönen, S. (2004) 'Organizational innovation capability: a driver for competitive superiority', International Review of Retail, Distribution and Consumer Research, Vol. 14, No. 3, pp.277-293. 
Un, C.A. and Cuervo-Cazurra, A. (2004) 'Strategies for knowledge creation in firms', British Journal of Management, Vol. 15, No. 1, pp.27-41.

Van den Bosch, F.A.J., Van Wijk, R. and Volberda, H.W. (2003) 'Absorptive capacity: antecedents, models and outcomes', in M. Easterby-Smith and M.A Lyles (Eds.): The Blackwell Handbook of Organizational Learning and Knowledge Management, pp.278-301, Blackwell Publishing, Malden.

Van den Bosch, F.A.J., Volberda, H.W. and de Boer, M. (1999) 'Coevolution of firm absorptive capacity and knowledge environment: organizational forms and combinative capabilities', Organization Science, Vol. 10, pp.551-568.

Vinding, A.L. (2006) 'Absorptive capacity and innovative performance: a human capital approach', Economics of Innovation and New Technologies, Vol. 15, pp.507-517.

Winter, S.G. (2003) ‘Understanding dynamic capabilities', Strategic Management Journal, Vol. 24, No. 10, pp.991-995.

Yli-Renko, H., Autio, E. and Sapienza, H.J. (2001) 'Social capital, knowledge acquisition and knowledge exploitation in young technology-based firms', Strategic Management Journal, Vol. 22, pp.587-613.

Zahra, S.A. and George, G. (2002) 'Absorptive capacity: a review, reconceptualization and extension', Academy of Management Review, April, Vol. 27, No. 2, pp.185-203.

\section{Notes}

1 It should be noted that the database cited here was created for wider purposes than those presented in this study; we therefore only use and present the questions and data relative to absorptive capacity. 


\section{Appendix}

Table A1 Organisational learning measurement scale

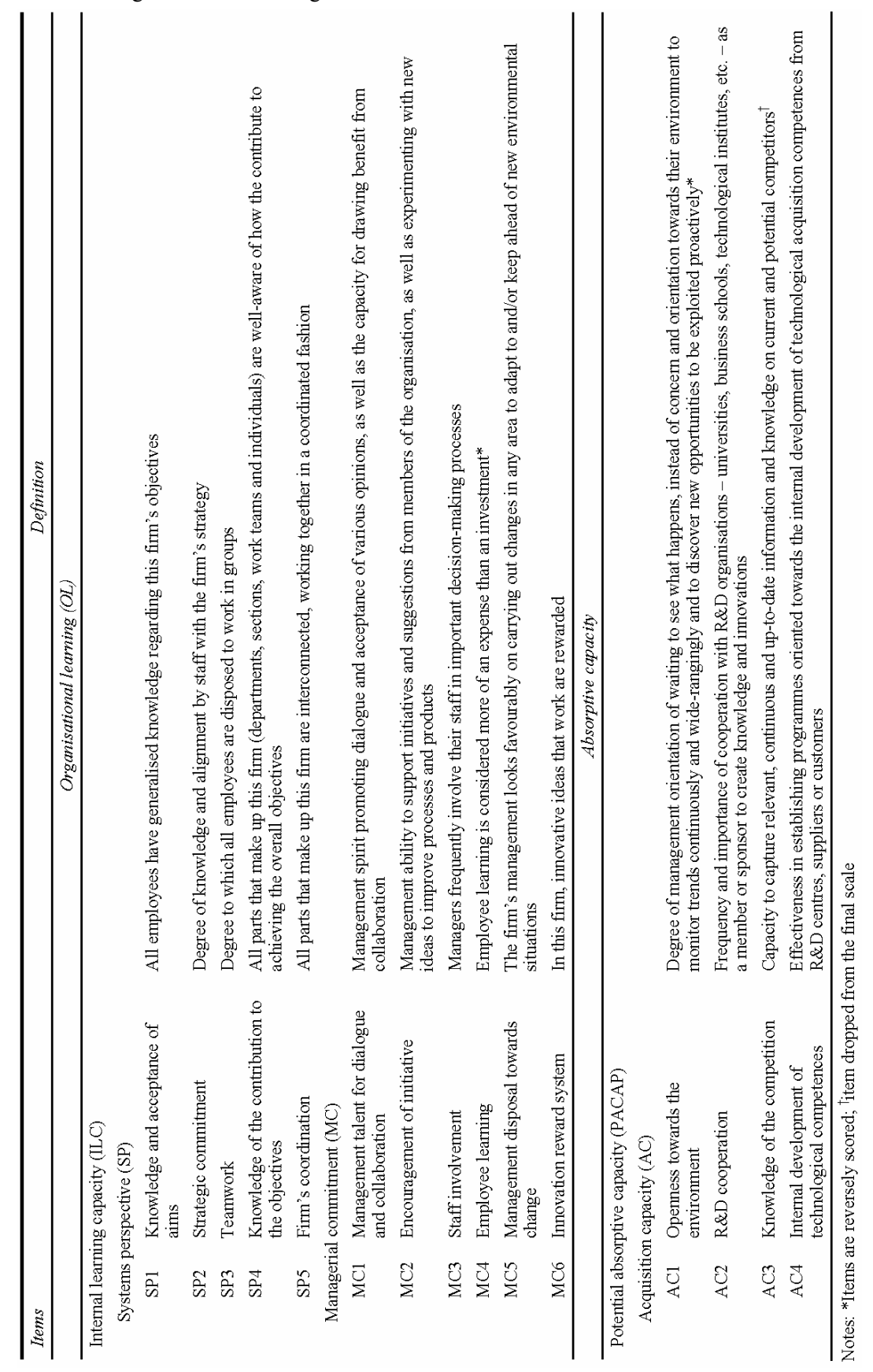


The complementary effect of internal learning capacity

Table A1 Organisational learning measurement scale (continued)

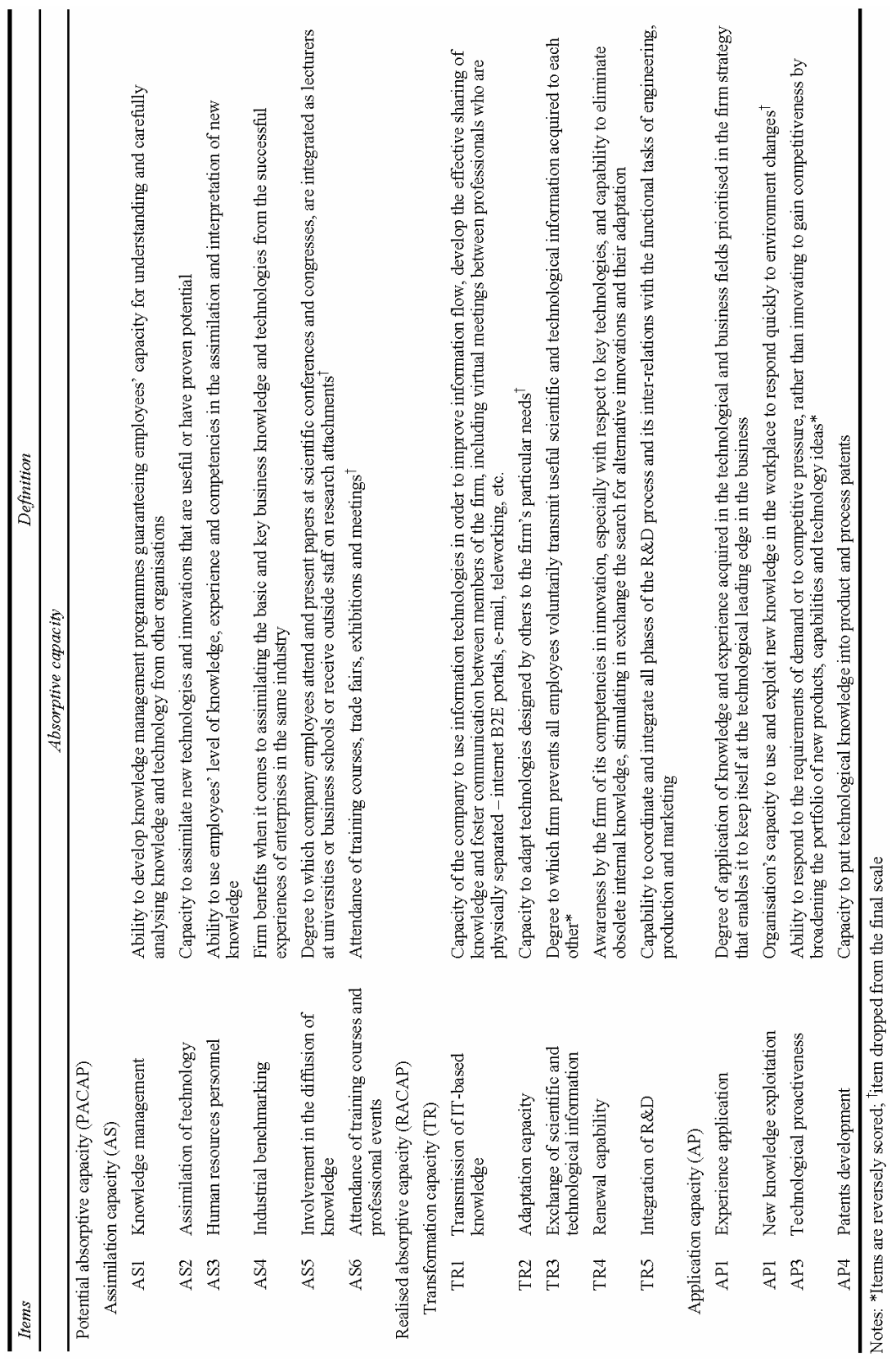


Table A2 Innovation capacity measurement scale

\begin{tabular}{|c|c|c|}
\hline Items & & Definition \\
\hline \multicolumn{3}{|c|}{ Innovation capacity (INCAP) } \\
\hline \multicolumn{3}{|c|}{ Product innovation (PRD) } \\
\hline IP1 & Product variety & Capacity to produce a wide variety of product \\
\hline IP2 & Specialised products & Capacity to offer specialised products \\
\hline IP3 & Product diversification & Ability to develop a diversified portfolio of products \\
\hline IP4 & First to market & $\begin{array}{l}\text { Ability to adjust the design of the product to the needs } \\
\text { of the customers to be the first to market }\end{array}$ \\
\hline IP5 & Product quality & Ability to offer high quality products \\
\hline IP6 & Product performance & Capacity for providing high-performance products \\
\hline IP7 & $\begin{array}{l}\text { Simplicity and ease of } \\
\text { use }\end{array}$ & $\begin{array}{l}\text { Ability to make products that are simple and easy to } \\
\text { use }\end{array}$ \\
\hline IP8 & $\begin{array}{l}\text { Technological product } \\
\text { differentiation }\end{array}$ & Ability to differentiate the product technologically \\
\hline \multicolumn{3}{|c|}{ Process innovation (PRC) } \\
\hline IPR1 & $\begin{array}{l}\text { Flexibility in planning } \\
\text { processes }\end{array}$ & $\begin{array}{l}\text { Capacity to develop planning processes for responding } \\
\text { quickly and effectively to frequent changes in } \\
\text { production capacity and customer needs }\end{array}$ \\
\hline IPR2 & Production organisation & $\begin{array}{l}\text { Capacity to develop creative, efficient and effective } \\
\text { processes or operational procedures for organising } \\
\text { production }\end{array}$ \\
\hline IPR3 & $\begin{array}{l}\text { Planning and control of } \\
\text { production }\end{array}$ & $\begin{array}{l}\text { Capacity to create effective processes or operational } \\
\text { procedures for planning and controlling production }\end{array}$ \\
\hline IPR4 & Speed of delivery & $\begin{array}{l}\text { Capacity to develop efficient processes for delivering } \\
\text { products and provide service quickly }\end{array}$ \\
\hline Table A3 & \multicolumn{2}{|c|}{ Business performance measurement scale } \\
\hline \multicolumn{3}{|c|}{ Organisational performance $(\mathrm{OP})$} \\
\hline OP1 & \multicolumn{2}{|c|}{ Average gross production margin } \\
\hline OP2 & \multicolumn{2}{|c|}{ Average economic profitability ROA } \\
\hline OP3 & \multicolumn{2}{|c|}{ Average financial profitability ROI } \\
\hline OP4 & \multicolumn{2}{|c|}{ Average profitability in sales ROS } \\
\hline
\end{tabular}

